\title{
Determinants of Polish Companies' Debt Financing Preferences
}

\author{
Anna Białek-Jaworska \\ University of Warsaw \\ ul. Dluga 44/50; 00-241 Warszaw, Poland
}

\section{Natalia Nehrebecka}

University of Warsaw

ul. Dluga 44/50; 00-241 Warszaw, Poland

National Bank of Poland

ul. Świętokrzyska 11/21; 00-919 Warsaw, Poland

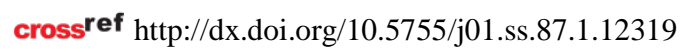

\begin{abstract}
The purpose of the paper is to identify determinants of the Polish non-finance companies' choices in respect of debt financing, with the monetary policy impact and the year effect taken into consideration. The study has been conducted using the system GMM method (robust), based on a research sample of corporate data of the years 1995-2012 (800 thousand observations). The correlation between profitability (self-financing) and debt financing is found to be negative in the group of large companies and the negative relationship between quick ratio and leverage observed regardless of the company size supports the pecking order theory. Furthermore, the analysis proves a very low influence of monetary policy on debt financing decisions of companies in Poland. The analysis showing how small and medium enterprises' payment gridlocks and small businesses' growth opportunities affect debt financing should help banks tailor their offer to the SME sector needs. The positive effect of the bankruptcy risk computed by means of a combination of traditional logistic regression with scoring methods on debt financing should influence bank loan committees' decisions when developing the creditworthiness assessment and loan application verification procedures. The value added here is the empirical proof of the statement that Poland's accession to EU and the access to EU grants reduced small enterprises' demand for external financing in the period 2004-2008, while the financial crisis in the EU states (2009-2010) triggered a decline in external financing.
\end{abstract}

Keywords: leverage, capital structure, pecking order theory, trade-off theory, system GMM.

\section{Introduction}

Analyses of corporate capital structures focus strongly on the company size. Both the trade-off theory and the pecking order theory point out the positive correlation between the company size and financial leverage, since greater diversification and lower variability of profits alleviate the problem of information asymmetry. According to Rajan and Zingales (1995), larger companies tend to be more diversified and experience financial problems less often. Hence, the company size can be an inverse approximation of the probability of bankruptcy and as such should have a positive effect on debt level. Company size can be therefore regarded as a proxy for the information asymmetry between the company and the market. Larger firms often disclose much more information than small businesses, thereby being able to increase their indebtedness on more favourable terms. Most studies reveal a positive effect of the company size on its financial leverage (e.g. Chen, 2004; Kim et al., 2006; Joeveer, 2013). In the case of New Zealand companies, the company size is negatively correlated with leverage within the low leverage value range and positively for high leverage values (Baum et al., 2009). A positive correlation between the company size and leverage is found by Jong et al. (2008), in their study of annual figures from 11000 firms across 42 countries for the period 1997-2001. They are attributing this correspondence to the fact that larger companies are more diversified and have more stable cash flows, being therefore regarded as lower-risk and more credit worthy borrowers. According to Chittenden et al. (1996), on the other hand, large companies have higher leverage than small firms owing to relatively lower cost of monitoring, as well as limited moral hazard and adverse selection.

Furthermore, researchers investigating capital structure are emphasizing the role of foreign ownership. Akhtar (2005) finds that collateral value of assets is a significant determinant of leverage for domestic corporations, while 
for multinationals - the number of foreign subsidiaries matters.

The purpose of the paper is to identify determinants of the Polish non-finance not only public companies' preferences in respect of debt financing, with the monetary policy impact and the year effect taken into consideration. With such independent variables as profitability, capability of generating cash surplus (operating cash flow computed by the indirect method) and liquidity taken into account, the paper aims to investigate, which of the economic theories: the pecking order theory or the trade-off theory describes companies' choices better as far as financing is concerned.

The study has been conducted using the system GMM (Generalised Methods of Moments) method (robust), based on a research sample of corporate data of the years 19952012 (800 thousand observations). Financial leverage is a subject of theoretical considerations and empirical studies based on unit data shown in companies' reports. Nevertheless, the papers referred to above do not provide any clear-cut conclusions. The present analysis expands on the existing knowledge of the factors determining the capital structure level of Polish firms. The study is an original work, as it has been carried out based on data of public and non-public, unlisted companies. What is more, attention should be given to the definition of the bankruptcy risk variable, which is computed in an innovative way, as well as to the variable representing the ability to generate cash surplus (operating cash flow computed by the indirect method). The ratio enabling assessment of the probability of company bankruptcy has been constructed through the combination of traditional logistic transgression and scoring methods. The paper has been structured as follows: the theoretical background and research hypotheses are presented in the initial section, followed by the presentation of empirical studies and findings interpreted and discussed with references to the literature of the subject. The paper ends with a summary and conclusions.

\section{Theoretical background and hypotheses}

The trade-off theory (Kraus and Litzenberger, 1973) postulates that an optimal capital structure exists for each company, where the incremental current value of tax shield from additional debt equals the incremental current value of financial cost of additional debt. Profitable companies paying higher corporate income taxes should use more loans, thereby increasing the leverage. The pecking order theory (Myers and Majluf, 1984; Myers, 1984) assumes that no optimal capital structure exists and emphasizes the problem of information asymmetry. Owing to information asymmetry between the company board and company owners and external investors, companies choose sources of capital with the lowest level of information gap, since publication of information is costly. Therefore, firms prefer internal sources of financing and are most willing to finance their business development with retained earnings. When the internally generated cash surplus turns out insufficient to cover capital expenditures, companies seek external funding with minimum risk involved, namely: bank loans, the issue of bonds and the issue of shares successively. This explains why some major and profitable corporations show a relatively low debt ratio. Mazur (2007) provides evidence that the pecking order theory is better applied in the Polish conditions than signalling. According to the idea of signalling, firms pay out dividend from their retained earnings to signal a good financial standing, thereby limiting their ability to finance development internally and being forced to use external funding. Bearing information asymmetry in mind, managers may use the capital structure as means of signalling the good financial standing of the company through borrowing. The credibility of signals sent by the company board increases with the managerial ownership of shares, the board being directly interested in the best corporate performance. Hence, the ownership structure plays an important role in analysis of the company capital structure. Vidal and Martin-Ugedo (2005) prove that highly leveraged companies tend to limit further borrowing and choose to issue shares or spend their retained earnings more than low-leverage companies do. However Brendea (2014) shows that the ownership structure has no significant effect on the target capital structure of Romanian firms. According to Garcia-Teruel et al. (2010), the quality of financial reporting is a tool reducing problems with information asymmetry, since companies with poor quality of reports use more short-term debt than companies exhibiting higher quality of financial reporting in a bank-oriented financial system.

Profitability. According to the pecking order theory, the proportion of external financing is negatively correlated with the company size and profitability, this however contradicts the trade-off theory, the bankruptcy cost theory and the theory of signalling (1977). From the trade-off theory point of view, more profitable companies should have higher leverage, since they generate higher income and may benefit more from the tax shield. Both Akdal (2010) and Myers (2001) point out that companies with a higher level of operating profit variability are characterized by a low value of debt rates. Mazur (2007) states that boards of prosperous Polish firms prefer selffinancing of developments to borrowing (negative estimation of the company profitability variable parameter). Margaritis and Psillaki (2007) report a positive impact of assets profitability on leverage owing to enhanced productivity from debt. On the other hand, Bauer (2004) obtained a negative correlation between profitability (EBIT / total assets) and leverage measured by a ratio of debt to debt plus equity book value ratio and leverage measured as liabilities to liabilities plus equity book value ratio. Kim et al. (2006) and Brendea (2014) confirm the negative impact of profitability on leverage. According to Dewaelheyns and Van Hulle (2010), profitability affects loans from affiliates adversely. Small, profitable businesses should have higher leverage, owing to the control function of debt (Jensen, 1986) and the benefits of using the interest tax shield which results from taking on debt (Frank and Goyal, 2003; Wu and Yue, 2009), this appearing to support the trade-off theory. Jong et al. (2008) obtain a negative - complying with the pecking order theory - correlation between profitability 
and leverage in 25 out of 42 companies analysed over the period 1997-2001. The above considerations lead us to Hypothesis 1: The use of debt financing shows a negative correlation with the company profitability.

Liquidity. Anderson (2002) finds evidence of a relation between liquid asset holding and leverage for British and Belgian firms, while Jong et al. (2008) report a negative impact of liquidity on leverage in developed economies and Nguyen (2014) for listed Vietnamese companies. Ozkan (2001) suggests that liquidity has an ambiguous effect on capital structure choices. The adverse impact of financial liquidity on debt level supports the pecking order theory against the signalling theory. Caldeira et al. (2014) show that higher levels of cash balances are associated to less leverage, and more levered firms are likely to hold less cash. Baum et al. (2009) prove a negative correlation between leverage and liquidity and profitability, this conforming to the pecking order theory. Jong et al. (2008) find liquidity to affect leverage negatively in developed economies rather. A higher quick ratio reduces the demand for external financing, as the need for commercial loan falls. The adverse relation supports the pecking order theory, according to which companies prefer internal financing to external financing. Liquidity can be regarded as a measure of internal funding availability. Hence, Hypothesis 2 can be put forward: Firms with a better quick liquidity show a lower debt ratio (the pecking order).

Collateral. According to the bankruptcy cost theory (Baxter, 1967), the increase in debt level translates into a growth of debt costs resulting from lenders' requirements in respect of the collateral value, thereby causing firms to choose internal financing rather. The bankruptcy costs level depends on the structure of assets, i.e. the higher the share of easily marketable tangible assets, the lower bankruptcy costs are, whereas a high share of intangible assets increases the cost of bankruptcy. The agency costs theory (Jensen and Meckling 1976; Myers, 1977) assumes the existence of an optimal capital structure, which minimizes agency costs, with a moderate involvement of external capital. The conflict between shareholders and lenders arises from the fact that greater risk is accepted where more benefits are expected. As only shareholders will benefit from the potential higher profits, creditors, whose risk is greater, require collateral, thereby increasing the cost of agency, which affects the capital structure in a similar way as bankruptcy costs do. Tangible assets are a measure of collateral value (Myers, 1977). More tangible assets reduce lender's risk and increase the availability of external financing. Information asymmetry and agency costs may make lenders demand a guarantee in the form of a fixed asset collateral, therefore a positive correlation between the share of fixed assets in total assets and the debt level was expected. Fixed assets can be used as collateral, thereby reducing the cost of debt agency (Rajan and Zingales, 1995). Kayo and Kimura (2011) report a positive effect of lower bankruptcy costs and agency costs on leverage. The findings presented in the studies referred to above are a basis for Hypothesis 3: The higher the tangible assets collateral (and the lower the bankruptcy costs and the agency costs), the higher the debt level is.
Growth opportunities. The literature of the subject assumes that companies with rapidly growing sales are at the stage of growth. Furthermore, sales growth can be regarded as a measure of risk (Danielson and Scott, 2004). One may expect that business growth opportunities have a similar effect on sources of financing as profitability. Goyal et al. (2002) as well as Barclay et al. (2006) report an adverse correlation between growth opportunities and debt-based financing. Jong et al. (2008) find that development opportunities have a negative impact on leverage in 24 out of 42 countries. According to Myers (1977), companies with development opportunities are characterized by lower leverage, since growth opportunities may generate an effect of moral hazard and greater inclination to risk. Akdal (2010) finds that companies with a high rate of return may be showing higher costs of bankruptcy and a lower debt level, whereas according to Michaelas et al. (1999), growth may encourage companies to decline to spend retained earnings and to borrow instead. On the one hand, growth opportunities initiate higher future revenue from sales, which, according to the pecking order theory, require a greater share of debt-based financing, but on the other hand they indicate high company value and hence may prompt the issue of new shares (Baker and Wurgler, 2002). Baker and Wurgler (2002) and Berk (2006) prove that the sales growth rate has a positive effect on leverage, but leverage does not explain a better financial performance. In the analysis study presented by Baker and Wurgler (2002), the return on equity is mostly determined by the turnover of assets. According to the signalling theory, profitable companies with growth opportunities should be relatively higher leveraged. Hence, Hypothesis 4 follows: Companies with greater growth opportunities show a relatively higher debt ratio.

Effective tax rate vs. tax shield. Hol and der Wijst (2008) find a significant impact of taxes on determinants of financial decision making in Norwegian non-listed companies. According to Degryse et al. (2012), the corporate income tax rate has a significant adverse effect on both total debt and long-term debt levels, while being positively - although not significantly - correlated with the short-term debt rate. High taxes follow high profits, the latter reducing the need to borrow (Jordan et al., 1998). Lee et al. (2014) show that the tax advantage of interest deductibility is a moderately important factor for Korean firms.

In the model presented by Miller and Modigliani, the so-called financial leverage effect results from the taxable income reduction through interest payments, in contrast to dividends paid out to shareholders. Owing to interest tax shield, the value of a company which uses external funding will be higher than that of a self-financing company. But an optimal capital structure is achieved with maximum debt and zero equity, with no financial risk, bankruptcy costs or agency costs taken into account. DeAngelo and Masulis (1980) include additionally non-debt tax shields, which reflect the taxable income reduction owing to depreciation, investment tax credits, cost of operating lease or tax credits for companies employing the disabled. The non-debt tax shield growth was accompanied by a decline 
in the interest tax shield level, owing to the substitution effect, and consequently - by the reduction in demand for external capital. Assuming that a negative taxable income has no effect on tax liabilities in the next years, the higher level of non-debt tax credits is accompanied by a lower share of external funds in the capital structure. Leverage decreases as the non-debt tax shield grows (Bauer, 2004, Kim et al., 2006, Chen, 2004 and Akdal, 2010). Heshmati (2002) suggests that the presence of a non-debt tax shield may reduce the optimal capital structure. Hence, the following hypotheses emerge: Hypothesis 5: Companies with a higher interest tax shield show a higher debt ratio. Medium and large firms with higher tax liabilities show a higher debt ratio. Hypothesis 5a: Companies with a higher non-debt tax shield show a lower debt ratio.

Tightening of monetary policy. De Haan and Sterken (2000) in their analysis of the lending channel of the monetary policy transmission in eleven Euro-zone countries prove that when reference rates grow, private companies' leverage decreases, particularly in terms of the bank loans sizes, while the role of trade loan increases as an alternative source of capital. Based on these findings a conclusion has been drawn that leverage, bank loans and short-term bank loans are restricted at the time of the monetary policy tightening. This effect is particularly strong in the category of private firms, while listed companies are most resistant. Ghosh and Sensarma (2004) find that a monetary policy-induced rise in the short-term interest rate reduces both interest sensitive investment spending and the corporate demand for bank loan. However, the implications of monetary tightening vary depending on debt maturity. According to the lending channel theory, monetary policy tightening constrains the supply of bank lending, thereby impacting the capital structure of bank-dependent firms. One might expect that public companies would be relatively less affected by a restrictive monetary policy, due to the lower degree of information asymmetry. On the other hand, the situation of private firms building long-term relations with banks, may be more favourable. Both public and private companies building long-term relations with banks may suffer less as a result of the monetary policy tightening. The analysis shows a decrease in the corporate debt ratio after monetary tightening, particularly for total debt, bank debt and shortterm debt, whereas trade debt has been observed to grow. Public companies are found to be more affected by negative monetary shocks to the short-term bank loan. Manufacturing firms are more responsive to monetary shocks than service firms and as a result of the monetary tightening they tend to lower their short-term bank borrowings. The empirical analysis below will verify the following Hypothesis 6: Monetary policy determines companies' capital structure via the interest rate channel and the currency exchange rate channel.

\section{Empirical study}

\subsection{Research sample}

The empirical analysis is based on company-specific balance sheet and profit and loss account data reported by
Polish firms in annual statistical reports F-02 and quarterly reports F-01/I-01 of the years 1995 - 2012. Since computing leverage as a proportion of total debt to total financing sources including non-positive equity and total debt would lead to wrong conclusions, observations with negative equity have been excluded from the sample. Otherwise, leverage would not be lower than 1, since negative equity would reduce total debt (the denominator would not be higher than the numerator). Over the years 1995-2011 as many as 93384 instances of negative equity are observed. Negative equity means that in the event of company liquidation, its assets will be insufficient to satisfy creditors and company owners forced to shut down the business will not recover whatever they contributed to the firm. The structure of the 1995-2012 sample shows that small firms prevail in number (about 66\%), while the share of major companies is smallest (5-7\%). Over the years, the share of small companies dropped to the advantage of medium-sized businesses. The intense growth of SMEs began following transformation and reforms initiated in 1989. A distinct period of growth is observable in the years 2005-2008, corresponding to the time of significant prosperity in the Polish economy. In the category of major companies, after a $10 \%$ decline in 2001, another fall - by some 5\% - was observed in 2009. The debt level was highest in the period 1999-2002 in a typical Polish firm (debt ratio around 0,5), while from the year 2007 on, the ratio median oscillated around 0.4 . The highest median of the effective tax rate was observed in the group of large companies. An average small firm is characterized by less growth opportunities than those available to an average medium-size and large firm. In 2002, an increase in interest tax shield was observed in all groups of companies. The interest tax shield median is similar for medium-sized and large companies and higher than the small firms' median. The cumulated return on equity distribution shows a left-sided asymmetry - the highest median is observed in the category of large firms. Payment gridlocks (the receivables turnover inverse) are showing a growing tendency across the analysed period. In 2011, an average large firm reports payment gridlocks at the level of 0,13 , while in the category of medium size and small firms these values are 0,12 and 0,11 respectively. Since 2003, quick ratios have been growing. The median is highest for large firms. The bankruptcy prediction distribution is similar in all of the analysed categories. An average small business has less collateral value of assets than a medium size and a large one.

\subsection{Definition of variables}

The structure of corporate financing can be measured by financial leverage. There is no consensus among corporate finance analysts about capital structure measures - none seems to be faultless and perfect. Rajan and Zingales (1995) argue that capital structure is best measured by means of total debt (external capital less provision for liabilities and corporate income tax) to total debt plus equity. Considering the non-public nature of the analysed companies and lack of any reliable market valuation in this respect, the book value of equity is 
Description of variables used in the financial leverage model

\begin{tabular}{|c|c|}
\hline Variable & Definition \\
\hline \multirow[t]{3}{*}{ 1. Financial leverage } & total debt \\
\hline & total debt + (equity-revaluation reserve) \\
\hline & $\begin{array}{l}\text { where: } \text { total debt }=\text { long-term }+ \text { short-term liabilities arising from issuance of debt securities, credits } \\
\text { and loans, as well as trade liabilities (trade loan) (without current expenditures) }\end{array}$ \\
\hline 2. Collateral & Fixed assets / Total assets \\
\hline 3. Cumulated return on equity & (Retained earnings + Capital reserves) / Equity \\
\hline $\begin{array}{l}\text { 4. Self-financing - dynamic approach } \\
\text { as a return measure }\end{array}$ & $\begin{array}{l}\text { Cash flows from operating activities computed by indirect method (Net profit (loss) + Total } \\
\text { adjustments)/(total debt + (equity -revaluation reserwe) }\end{array}$ \\
\hline 5. Quick ratio measure & (Current assets - Inventories) / Short-term liabilities \\
\hline 6. Non-debt tax shield & Depreciation / (total debt + (equity -revaluation reserwe)) \\
\hline 7. Interest tax shield & Interest / Total assets \\
\hline 8. Growth opportunities & $($ Sales $(\mathrm{t})$ - Sales $(\mathrm{t}-1))$ / Sales $(\mathrm{t}-1)$ \\
\hline 9. Effective tax rate & Corporate Income Tax / Pre-Tax Profit \\
\hline 10. Payment gridlock measure & Trade receivables / Sales \\
\hline 11. Inverse bankruptcy prediction rate* & Nehrebecka and Dzik (2012) \\
\hline 12. WIBOR3M & 3-month WIBOR interest rate \\
\hline 13.Effective currency rate of exchange & Effective currency rate of exchange \\
\hline
\end{tabular}

* Inverse bankruptcy prediction rate $=1 /$ (bankruptcy prediction rate from the (0-1000) range. The greater the probability of bankruptcy, the lesser denominator and the greater inverse bankruptcy prediction rate is.

accepted here. For the purpose of this study, this measure will be adapted to the Polish conditions, i.e. equity will be reduced by revaluation reserve, which is only an accrualbased effect of the long-term assets valuation as per market value or otherwise determined fair value. According to Polish accounting standards, revaluation reserve is created as a result of valuation of long-term financial investments, real estate investments until 2009, and in 1996 - also fixed assets, pursuant to the Ordinance of the Minister of Finance on Compulsory Revaluation of Fixed Assets Value. Following literature overview, a list of potential leverage determinants has been defined. Financial leverage determinants have been analysed using variables, such as financial and macroeconomic ratios, as well as structural factors. Table 1 presents a complete description of variables used in the empirical analysis.

\subsection{Research method}

Based on the literature of the subject referred to above, a dynamic econometric model has been designed, describing how financial leverage of non-financial companies in Poland is affected by three categories of factors: macroeconomic, microeconomic - associated with the internal financial situation and structural (e.g. legal status, direction of sales).

The models presented in the paper include estimations of individual effects, sector-specific effects and timerelated effects. Parameters have been computed using the robust, system GMM (Generalised Methods of Moments) estimator (Arellano and Bover, 1995; Blundell and Bond,
1998). It is an undoubted advantage of the system GMM method that it allows including endogenous or weakly exogenous variables. The correlation of random component and endogenous variables is eliminated through the inclusion of variables (so-called instruments) strongly correlated with explanatory variables, but independent on random error. The system GMM procedure uses diverse instruments in equations and lagged instruments in difference-based equations. A combination like this allows elimination of autocorrelation and of the endogeneity problem from the model, thereby reducing the bias of estimators. The system GMM estimator can be used in case of a missing variable, measurement errors or a feedback between the dependent and explanatory variable. On the other hand, the problem with methods based on GMM is that they are restricted to too short time series. For the econometric model to reflect the analysed problem correctly, the panel sample should include observations from several periods of time. More detailed descriptions of methods based on Generalised Methods of Moments are given by Mátyás and Sevestre (2008) or Blundell and Bond (1998). The models have been diagnosed in terms of the instruments selection correctness by means of Sargan test and a test for autocorrelation in differences of model residuals, checking whether the condition of instruments and random component combined orthogonality has been satisfied. The model design assumptions require that no residual component correlation of order 2 or higher can be present. An analysis of descriptive statistics and histograms of continuous variables shows a significant percent of atypical observations in all samples. Taking the 
distribution of probability into account, $5 \%$ of the outermost values have been replaced with the 0,95 quantile or 0,05 quantile value at the same time, depending on the property distribution. This allows analysis of relations between the variability of dependent variable and the variability of explanatory variables without any loss of essential information. Before the econometric analysis, the correlation between explanatory variables has been estimated. Detailed outcomes of Spearman's ranks correlation are presented in Tables 2-4. Factors determining financial leverage in companies have been analysed in a breakdown by company sizes. Two models have been estimated for each of the three categories: small, medium and large firms. Effect of the year has been taken into account in model I, II, III, while models IV, V, VI have been expanded with control variables for the macroeconomic environment conditions, WIBOR and the effective currency rate (Table 5, Annex 1).

\section{Findings}

The findings reveal that small companies follow a stable strategy of external financing, especially the longterm one. The positive parameter of binary variables for the years 1999-2001 means that leverage grows in the period of prosperity, which is the case in small and large firms in particular. Poland's accession to the European Union reduced small enterprises' demand for external financing in the years 2004-2008 owing to the access to a wider market inside EU and to EU grants, while the financial crisis experienced by EU Member States restricted the availability of external financing. Contrary Brendea (2013) pointed out, that during the recent financial crisis Romanian listed firms used more debt as a result of the reduction of their internal financing resources and the low market value of their equity during the crisis.

Small foreign firms are less in need of external funding than small domestic businesses. The demand for external financing is more characteristic for small trade companies than for small manufacturers. Medium size service companies show lower leverage than medium size manufacturers, on the other hand. Medium size and large limited partnerships are more in need of external funding than other partnerships, since tax optimization opportunities encourage businesses to focus on development supported from external sources. Limited liability companies are characterized by a lower leverage than partnerships, due to risks to business continuity involved in excessive indebtedness and decrease in share capital induced by significant financial losses. Small stateowned enterprises seek less external funding than partnerships. Based on the analysis of outcomes (Table 5, Annex 1), hypothesis 1 has not been rejected for large firms only, since an adverse correlation between debtbased financing and business profitability is found if the operating cash flow divided by external and internal funding is taken as a profitability measure. Large firms generating a higher financial surplus have a lower financial leverage, owing to their self-financing capability, just as assumed by the pecking order theory.

On the other hand, the positive correlations observed in small and medium size enterprises' self-financing in period $t$ or $t-1$ comply with the trade-off theory and the transaction costs theory. The estimated models prove that the growth of cumulated return on equity (share of retained earnings and capital reserves in equity) giving evidence to large firms' higher self-financing potential, increases the use of external funding, thereby supporting the trade-off theory. In case of large companies, the ability to generate profit and implement the business plan plays a more important role than collateral assets. More profitable small enterprises with a greater self-financing potential shown by dynamic analysis, report a greater demand for external funding owing to cash surplus generated from their business, which seems to support the trade-off theory.

The negative correlation between leverage and quick ratio complies with the expectations defined in hypothesis 2 based on the literature overview (inter alia: Jong et al., 2008; Baum et al., 2009, as well as Akdal, 2010).

Analysis of the explanatory variables correlation in the small business financial leverage model

\begin{tabular}{|c|c|c|c|c|c|c|c|c|c|c|c|}
\hline No & 1 & 2 & 3 & 4 & 5 & 6 & 7 & 8 & 9 & 10 & 11 \\
\hline 1 & 1,000 & & & & & & & & & & \\
\hline 2 & $0,167 *$ & 1,000 & & & & & & & & & \\
\hline 3 & $0,037 *$ & $\widetilde{0,134^{*}}$ & 1,000 & & & & & & & & \\
\hline 4 & $0,032^{*}$ & $0,023^{*}$ & $0,030^{*}$ & 1,000 & & & & & & & \\
\hline 5 & $\stackrel{-}{0,590^{*}}$ & $\widetilde{0,147^{*}}$ & $0,040^{*}$ & $0,044^{*}$ & 1,000 & & & & & & \\
\hline 6 & $0,066^{*}$ & $0,358^{*}$ & $0,032^{*}$ & $0,261^{*}$ & $0,010^{*}$ & 1,000 & & & & & \\
\hline 7 & $0,310^{*}$ & $0,075^{*}$ & $0,048^{*}$ & $0,034^{*}$ & $0,252^{*}$ & $0,113^{*}$ & 1,000 & & & & \\
\hline 8 & $0,040^{*}$ & $\begin{array}{c}0,036^{*} \\
\end{array}$ & $0,026^{*}$ & $0,125^{*}$ & $0,041^{*}$ & $0,008^{*}$ & $\begin{array}{c}- \\
0,054^{*}\end{array}$ & 1,000 & & & \\
\hline 9 & $-0,002$ & $\stackrel{-}{0,177^{*}}$ & $0,057 *$ & $0,067 *$ & $0,114^{*}$ & $\overline{0}-\overline{007 *}$ & $0,061^{*}$ & $0,200^{*}$ & 1,000 & & \\
\hline 10 & $0,095^{*}$ & $0, \overline{195 *}$ & $-0,000$ & $0,128^{*}$ & $0,260^{*}$ & $0,086^{*}$ & $0,104^{*}$ & $0,014^{*}$ & $0,074^{*}$ & 1,000 & \\
\hline 11 & $\begin{array}{r}- \\
0,188^{*}\end{array}$ & $0,157 *$ & $0,028^{*}$ & $0,315^{*}$ & $0,379^{*}$ & $0,041^{*}$ & $\begin{array}{c}- \\
0,028^{*}\end{array}$ & $0,182^{*}$ & $0,231^{*}$ & $0,093^{*}$ & 1,000 \\
\hline
\end{tabular}


Analysis of the explanatory variables correlation in the medium size business financial leverage model

\begin{tabular}{|c|c|c|c|c|c|c|c|c|c|c|c|}
\hline No & 1 & 2 & 3 & 4 & 5 & 6 & 7 & 8 & 9 & 10 & 11 \\
\hline 1 & 1,000 & & & & & & & & & & \\
\hline 2 & $0,227^{*}$ & 1,000 & & & & & & & & & \\
\hline 3 & $0,095 *$ & $-0,210^{*}$ & 1,000 & & & & & & & & \\
\hline 4 & $-0,043^{*}$ & $-0,002$ & $0,061^{*}$ & 1,000 & & & & & & & \\
\hline 5 & $-0,627^{*}$ & $-0,169 *$ & $0,012^{*}$ & $0,056^{*}$ & 1,000 & & & & & & \\
\hline 6 & $-0,089 *$ & $0,333^{*}$ & $-0,050^{*}$ & $0,313^{*}$ & $-0,010^{*}$ & 1,000 & & & & & \\
\hline 7 & $0,393^{*}$ & $-0,002$ & $-0,010^{*}$ & $0,023^{*}$ & $-0,315^{*}$ & $0,095 *$ & 1,000 & & & & \\
\hline 8 & $0,068^{*}$ & $-0,071^{*}$ & $-0,036^{*}$ & $0,117^{*}$ & $0,035^{*}$ & $-0,035^{*}$ & $-0,045^{*}$ & 1,000 & & & \\
\hline 9 & $-0,045$ & $-0,141^{*}$ & $0,052^{*}$ & $0,030^{*}$ & $0,131^{*}$ & $-0,048^{*}$ & $-0,085^{*}$ & $0,156^{*}$ & 1,000 & & \\
\hline 10 & $0,041^{*}$ & $-0,301^{*}$ & $-0,004$ & $-0,116^{*}$ & $0,311^{*}$ & $-0,125^{*}$ & $0,103^{*}$ & $-0,005^{*}$ & $0,035 *$ & 1,000 & \\
\hline 11 & $-0,360^{*}$ & $-0,168^{*}$ & $0,055^{*}$ & 0,293* & 0,533* & $0,062^{*}$ & $-0,200^{*}$ & $0,186^{*}$ & $0,268^{*}$ & $0,083^{*}$ & 1,000 \\
\hline
\end{tabular}

\section{Analysis of the explanatory variables correlation in the large business financial leverage model}

\begin{tabular}{|c|c|c|c|c|c|c|c|c|c|c|c|}
\hline No & 1 & 2 & 3 & 4 & 5 & 6 & 7 & 8 & 9 & 10 & 11 \\
\hline 1 & 1,000 & & & & & & & & & & \\
\hline 2 & $-0,227^{*}$ & 1,000 & & & & & & & & & \\
\hline 3 & $0,120^{*}$ & $-0,218^{*}$ & 1,000 & & & & & & & & \\
\hline 4 & $-0,076^{*}$ & $0,046^{*}$ & $0,060^{*}$ & 1,000 & & & & & & & \\
\hline 5 & $-0,643^{*}$ & $-0,179^{*}$ & 0,007 & $0,039 *$ & 1,000 & & & & & & \\
\hline 6 & $-0,085^{*}$ & $0,375^{*}$ & $-0,095^{*}$ & $0,355^{*}$ & $-0,024^{*}$ & 1,000 & & & & & \\
\hline 7 & $0,479^{*}$ & $-0,028^{*}$ & $0,046^{*}$ & $-0,014^{*}$ & $-0,380^{*}$ & $0,063^{*}$ & 1,000 & & & & \\
\hline 8 & $0,087 *$ & $-0,088^{*}$ & $-0,045^{*}$ & $0,057^{*}$ & 0,009 & $-0,071^{*}$ & $-0,041^{*}$ & 1,000 & & & \\
\hline 9 & $-0,092^{*}$ & $-0,113^{*}$ & $0,030^{*}$ & $0,081^{*}$ & $0,153^{*}$ & $-0,043^{*}$ & $-0,150^{*}$ & $0,163^{*}$ & 1,000 & & \\
\hline 10 & $0,085^{*}$ & $-0,353^{*}$ & $0,095 *$ & $-0,140^{*}$ & $0,267^{*}$ & $-0,176^{*}$ & $0,133^{*}$ & $-0,009$ & $-0,010^{*}$ & 1,000 & \\
\hline 11 & $-0,389 *$ & $-0,165^{*}$ & $0,064^{*}$ & $0,261 *$ & $0,541^{*}$ & $0,030 *$ & $-0,272^{*}$ & $0,162^{*}$ & $0,289^{*}$ & $0,061^{*}$ & 1,000 \\
\hline
\end{tabular}

This supports the pecking order theory, according to which companies prefer internal funding to external funding. Liquidity can be regarded as a measure of internal funding availability. A higher quick ratio reduces the demand for external financing, owing to a lower demand for trade loan. In medium size and large companies, the demand for external funding drops in year $t$ as a result of the fixed assets growth, since some of the capital expenditures have already been made. In small and medium size firms, on the other hand, fixed assets owned in year $t-1$ increase the financial leverage, since they act as a collateral, thereby making loans more accessible. This is the case because creditworthiness is verified based on financial reports of the previous year. The negative correlation between the year's collateral and leverage observed in the category of small and medium enterprises supports hypothesis 3. A similarly positive impact of lower bankruptcy costs and agency costs on leverage is observed by Kayo and Kimura (2011).

The analysis (Table 5, Annex 1) shows that fast growing small businesses have greater financial needs, therefore they will be more inclined to borrow, which supports hypothesis 4 in respect of small enterprises. The group of researchers reporting positive correlation between leverage and business growth opportunities includes also Serrasqueiro et al. (2011). Sales growth is not capable of satisfying small firms' financial needs, due to payment gridlocks which play a much more crucial role in this segment. In medium size and large companies, on the other hand, growth of sales enhances the self-financing potential (owing to higher revenue from sales), thereby reducing the demand for external funding. Payment gridlock are much less important to medium size and large firms, therefore sales growth is accompanied by higher cash receipts. Payment gridlocks in SMEs build up the demand for external funding in SMEs in year $t$, especially in small firms. Furthermore, in year t-1 they restrain the ability to service debt, thereby reducing the leverage and limiting access to external financing.

Debt-based financing offers medium size and large firms an opportunity to save on taxes, thereby increasing the financial leverage of companies paying high taxes (with a high effective tax rate in the previous period t-1). The findings support hypothesis 5. Higher taxes follow higher revenue, which in turn reduces the need to take on debt (Jordan et al., 1998). The official tax rate is statistically significant and has a negative effect on leverage (Joeveer, 2013).

The findings show (Table 5, Annex 1) that tax savings resulting from deduction of e.g. interest on debt from taxable income increase corporate leverage regardless of the company size. This indicates that there are no grounds for rejecting hypothesis 5. Lee et al. (2014) receive similar findings - nearly one-third of the respondents in their survey indicate that the tax advantage of interest deductibility is important or very important in their choice of capital structure. On the other hand, the non-debt tax shield definitely reduces the leverage of medium size companies in period t, indicating that medium size companies save on taxes owing to depreciation rather than to interest on debt paid (a definitely stronger effect of the non-debt shield on leverage than that of the interest tax 
shield). This supports hypothesis $5 a$ for medium size companies. A similar correlation is reported by other researchers, including Kayo and Kimura (2011). The effect of non-debt tax shield in the group of large and medium size firms in period $(t-1)$ is similar to the effect of interest tax shield.

The positive correlation translates into the financial leverage growth occurring as a result of debt cost depreciation through higher tax savings.

Companies with sound finances and a low probability of bankruptcy tend to keep their debt level low. Small businesses are definitely less inclined to borrow in hard times than large companies, since the risk of bankruptcy caused by excessive debt is much higher for them. Akdal (2010) and Myers (2001) report that companies with a higher degree of operating profit variation are characterized by a low debt rate. In medium size firms, bankruptcy risk does not have any significant effect on leverage, as leverage rates are lowest in this group of businesses (until 2004 inclusive). From 2005, the average leverage of medium size companies was lower than that of small companies.

\section{Monetary policy impact}

Monetary policy reduces large companies’ financial leverage via the interest rate channel, which indicates that there are no grounds for rejecting hypothesis 6 according to which monetary policy determines companies' financing structure. The higher WIBOR3M of the current period, the lower the large companies' financial leverage is. The effect of monetary policy exerted on small and medium size companies' financial leverage via the interest rate channel is lagged. WIBOR3M lagged two periods reduces small and medium sized enterprises' financial leverage. In case of large companies, the effect of the current WIBOR3M shows the same direction. Monetary policy reduces SME's financial leverage via the currency exchange rate channel. The effective exchange rate lagged one period has a positive effect on the external financing level, including foreign loans or borrowing, while if lagged two periods, it reduces the share of external funding in the medium size companies' capital structure. This indicates that there are no grounds for rejecting hypothesis 6 , according to which monetary policy determines companies' financing structure (via the currency exchange rate channel). With the real WIBOR3M interest rate and real, effective exchange rate, the conclusions concerning the impact of monetary policy on large companies' financing structure remain unchanged as compared with the model where the nominal interest rate and the nominal effective exchange rate are used. Models IV, VII and VIII indicate the same direction of the real and nominal WIBOR3M influence on large companies' leverage, while the estimation based on real interest rate allows observing a lower impact (factor value $-0,10$ for nominal WIBOR3M against $-0,07 *$ for real WIBOR3M and $0,15^{* * *}$ for nominal WIBOR3M lagged one period against $0,14^{* * *}$ for real WIBOR3M lagged one period). Similarly, models IV, VII and VIII indicate the same direction of the real and nominal effective exchange rate impact on large companies' financial leverage, while the estimation based on real exchange rate lagged one period allows observing a lower impact (factor value $0,08 * * *$ for nominal effective exchange rate lagged one period against $0,05^{* *}$ for real effective exchange rate lagged one period). Furthermore, real WIBOR3M and real effective exchange rate are correlated, which renders it impossible to include them in the model together and to verify the monetary policy impact via the interest rate and exchange rate channels. It can therefore be presumed that conclusions concerning the direction of the monetary policy impact on companies' financing structure would be the same with the real WIBOR3M and real effective exchange rate as with nominal interest rates and exchange rates, although the value of factors, i.e. the impact would be lower.

\section{Summary and final conclusions}

The conducted research results show a negative correlation between profitability (the self-financing potential measured by operating cash flow) and debt-based financing for large firms, according to the pecking order theory, but a positive one for small and medium size companies, which supports the trade-off theory and the transaction costs theory. The negative correlation between quick ratio and leverage, regardless of the company size indicates that Polish firms' preferences in respect of debt financing follow the pecking order theory. Furthermore, the pecking order theory is supported by empirical studies published by: Bauer (2004), Vidal and Martin-Ugedo (2005) for SMEs with a higher growth level, Berk (2006); Munyo (2006); Daskalakis and Psillaki (2008); Crnigoj and Mramor (2009); Baum et al. (2009); Akdal (2010); Bhaird and Lucey (2010); Vanacker and Manigart (2010); Degryse et al. (2012); Frank and Goyal (2003) as well as Rocca et al. (2011) especially for older firms; Vanacker and Manigart (2010), but in a more extensive version, with the limited creditworthiness taken into account; while Jong et al. (2008) for 25 out of 42 countries.

The main determinants of debt financing of Polish companies are the lagged non-debt tax shield (depreciation costs based on fixed assets) and the higher bankruptcy risk. However small businesses are less inclined to borrow in hard times than large companies, since the risk of bankruptcy caused by excessive debt is much higher for them. The important factor of loans accessibility for small and medium size firms are fixed assets since they act as a collateral. Tax savings resulting from deduction of interest on debt from taxable income increase corporate leverage. However Polish medium size companies save on taxes owing to depreciation rather than to interest on debt paid. The research reveal that payment gridlocks in Polish small and medium sized companies and small businesses' growth opportunities build up the demand for external funding. The results of the study are important for policymakers as increasing their knowledge of the collateral role and (investments in fixed assets) in improving of access to debt-finance. The implementation of the instruments to solve the problem of payment gridlocks in Polish SMEs is also important. 
The findings show that Poland's accession to EU and the access to EU grants reduced small firms' demand for external financing in the period 2004-2008 despite wider access to foreign loans. But the financial crisis in the EU states (2009-10) triggered a decline in external financing.

As a result of conducted research, an observation has been made that small foreign firms are less in need of external funding than domestic businesses. The demand for external financing is more characteristic for small trade companies than for small manufacturers. Medium size service companies show lower financial leverage than medium size manufacturers, on the other hand. Medium size and large limited partnerships are more in need of external funding than other partnerships, since tax optimization opportunities encourage businesses to focus on development supported from external sources.

Limited liability companies are characterized by a lower leverage than partnerships, most probably due to risks to business continuity involved in excessive indebtedness. Small state-owned enterprises seek less external funding than partnerships. Moreover, a very low impact of monetary policy on companies' choices in respect of external financing has been proved, whether exerted via the interest rate channel or the exchange rate channel. The findings point that the effect of monetary policy exerted on small and medium size companies' financial leverage via the interest rate channel is lagged.

As compared with the existing studies on the capital structure of Polish firms (Hussain and Nirvorozhkin, 1997; Mazur, 2007; Kędzior, 2011), the paper distinguishes an empirical analysis of an extensive sample of Polish companies, including limited liability companies, partnerships and civil law partnerships, as well as the extensive time range of the sample - as much as 18 years, from 1995 through 2012.

Since the main limitation of the study is the measure leverage and the exclusion of observations with negative equity, directions for future research will focus on a separate analysis of the short- and long-term capital structure, measured in relation to total assets and the extension the research sample by data for 2013.

\section{Acknowledgment}

The article is a fragment of the research project conducted under the NBP open competition for research projects to be carried out in 2013 and was financed by Narodowy Bank Polski (project manager - Dr Natalia Nehrebecka, Assistant Professor at the Department of Econometrics and Statistics, the University of Warsaw).

\section{References}

1. Akdal, S. (2010). How do Firm Characteristics Affect Capital Structure? Some UK Evidence. MPRA Paper, 29657.

2. Akhtar, S. (2005). Australian Multinational and Domestic Corporations Capital Structure Determinants. Australian Journal of Management, 30, 321-341. http://dx.doi.org/10.1177/031289620503000208

3. Anderson, R. W. (2002). Capital structure, firm liquidity and growth. National Bank of Belgium Working Papers, 27.
4. Arellano, M., \& Bover, O. (1995). Another look at the instrumental variable estimation of error-components models. Journal of econometrics, $68 \quad$ (1), 29-51. http://dx.doi.org/10.1016/03044076(94)01642-D

5. Baker, M., \& Wurgler, J. (2002). Market timing and capital structure. Journal of Finance, 57, (1), 1-32. http://dx.doi.org/10.1111/1540-6261.00414

6. Barclay, M. J., Morellec, E., \& Smith Jr., C.W. (2006). On the debt capacity of growth opportunities. Journal of Business, 79, (1), 3759. http://dx.doi.org/10.1086/497404

7. Bauer, P. (2004). Determinants of Capital Structure: Empirical Evidence from the Czech Firms. Czech Journal of Economics and Finance, 54, (1-2), 2-21.

8. Baum, Ch. F., Stephan, A., \& Talavera, O. (2009). The Effects of Uncertainty on the Leverage of Nonfinancial Firms. Economic Inquiry, 47, (2), 216-225. http://dx.doi.org/10.1111/j.14657295.2007.00116.x

9. Baxter, N. D. (1967). Leverage, risk of ruin and the cost of capital. Journal of Finance, 22, (3), 395-403.

10. Berk, A. (2006). Determinants of leverage in Slovenian Blue-Chip Firms and Stock Performance Following Substantial Debt Increases. Post-Communist Economies, 18, (4), 479-494. http://dx.doi.org/10.1080/14631370601008621

11. Bhaird, C., \& Lucey, B. (2010). Determinants of capital structure in Irish SMEs. Small Business Economics, 35, (3), 357-375. http://dx.doi.org/10.1007/s11187-008-9162-6

12. Blundell, R., \& Bond, S. (1998). Initial conditions and moment restrictions in dynamic panel data models. Journal of Econometrics, 87, (1), 115-143. http://dx.doi.org/10.1016/S03044076(98)00009-8

13. Brendea, G. (2013). The impact of the recent financial crisis on the capital structure choices of the Romanian listed firms. Review of Economic Studies and Research Virgil Madgearu, 6, (2), 15-26.

14. Brendea, G. (2014). Financing Behaviour of Romanian Listed Firms in Adjusting to the Target Capital Structure. Finance a úvěrCzech Journal of Economics and Finance, 64, (4), 312-329.

15. Caldeira, J., \& Loncan, T. R. (2014). Capital structure, cash holdings and firm value: a study of Brazilian listed firms. Revista Contabilidade \& Finanças - USP, Săo Paulo, 25, (64), 46-59.

16. Chen, J. J. (2004). Determinants of capital structure of Chineselisted companies. Journal of Business Research, 57, (12), 13411351. http://dx.doi.org/10.1016/S0148-2963(03)00070-5

17. Chittenden, F., Hall, G., \& Hutchinson, P. (1996). Small firm growth, access to capital markets and financial structure: Review of issues and an empirical investigation. Small Business Economics, 8, (1), 59-67. http://dx.doi.org/10.1007/BF00391976

18. Crnigoj, M., \& Mramor, D. (2009). Determinants of Capital Structure in Emerging European Economies: Evidence from Slovenian Firms. Emerging Markets Finance \& Trade, 45, (1), 7289. http://dx.doi.org/10.2753/REE1540-496X450105

19. Danielson, M. G., \& Scott, J. A. (2004). Bank Loan Availability and Trade Credit Demand. The Financial Review, 39. http://dx.doi.org/10.1111/j.0732-8516.2004.00089.x

20. Daskalakis, N., \& Psillaki, M. (2008). Do country or firm factors explain capital structure? Evidence from SMEs in France and Greece. Applied Financial Economics, 18, 87-97. http://dx.doi.org/10.1080/09603100601018864 
Social Sciences /

Socialiniai mokslai. 2015. Nr. 1 (87)

21. de Haan, L., \& Sterken, E. (2000). Capital Structure, Corporate Governance, and Monetary Policy: Firm-Level Evidence for the Euro Area. De Nederlandsche Bank, Research Memorandum WO\&E, 637/0032.

22. de Jong, A., Kabir, R., \& Nguyen, T. T. (2008). Capital structure around the world: The roles of firm- and country-specific determinants. Journal of Banking \& Finance, 32, (9), 1954-1969. http://dx.doi.org/10.1016/j.jbankfin.2007.12.034

23. DeAngelo, H., \& Masulis, R. W. (1980). Optimal capital structure under corporate and personal taxation. Journal of Financial Economics, 8, 3-29. http://dx.doi.org/10.1016/0304405X(80)90019-7

24. Degryse, H., de Goeij, P., \& Kappert, P. (2012). The impact of firm and industry characteristics on small firms capital structure. Small Business Economics, 38, 431-447. http://dx.doi.org/10.1007/s11187-010-9281-8

25. Dewaelheyns, N., \& Van Hulle, C. (2010). Internal capital markets and capital structure: Bank versus internal debt. European Financial Management, 16, (3), 345-373. http://dx.doi.org/10.1111/j.1468-036x.2008.00457.x

26. Frank, M. Z., \& Goyal, V. K. (2003). Testing the pecking order theory of capital structure. Journal of Financial Economics, 67, (2), 217-248. http://dx.doi.org/10.1016/S0304-405X(02)00252-0

27. García-Teruel, P. J., Martínez-Solano, P., \& Sánchez-Ballesta, J. P. (2010). Accruals Quality and Debt Maturity Structure. Abacus, 46, (2), 188-210. http://dx.doi.org/10.1111/j.1467-6281.2010.00312.x

28. Ghosh, S., \& Sensarma, R. (2004). Does monetary policy matter for corporate governance? Firm-level evidence from India. In M. Hirschey, J. Kose, A. K. Makhija, Corporate Governance, Advances in Financial Economics, 9, 327-353. http://dx.doi.org/10.1016/s1569-3732(04)09013-9

29. Goyal, V. K., K. Lehn, \& S. Racic. (2002). Growth opportunities and corporate debt policy: the case of the US defense industry. Journal of Financial Economics, 64, (1), 35-59. http://dx.doi.org/10.1016/S0304-405X(02)00070-3

30. Heshmati, A. (2002). The Dynamics of Capital Structure: Evidence from Swedish Micro and Small Firms. Research in Banking and Finance, 2, 199-241.

31. Hol, S., \& der Wijst, N. V. (2008). The financial structure of nonlisted firms. Applied Financial Economics, 18, 559-568. http://dx.doi.org/10.1080/09603100601057839

32. Hussain, Q., \& Nivorozhkin, E. (1997). The Capital Structure of Listed Companies in Poland. IMF Working Papers, WP/97/175. http://dx.doi.org/10.5089/9781451976342.001

33. Jensen, M., \& Meckling, W. (1976). Theory of the firm: Managerial behaviour, agency cost and capital structure. Journal of Financial Economics, 3, 305-360. http://dx.doi.org/10.1016/0304-405X(76)90026-X

34. Jensen, M. C. (1986). Agency Cost of Free Cash flow, Corporate Finance, and Takeovers. American Economic Review, 76, (2), 323329.

35. Joeveer, K. (2013). What do we know about capital structure of small firms? Small Business Economics, 41, 479-501. http://dx.doi.org/10.1007/s11187-012-9440-1

36. Jordan, J., Lowe, J., \& Taylor, P. (1998). Strategy and financial policy in UK small firms. Journal of Business Finance and Accounting, 25, (1\&2), 1-27. http://dx.doi.org/10.1111/14685957.00176
A. Biatek-Jaworska, N. Nehrebecka. Determinants of Polish Companies' Debt Financing Preferences

37. Kayo, E. K., \& Kimura, H. (2011). Hierarchical Determinants of Capital Structure. Journal of Banking and Finance, 35, 358-371. http://dx.doi.org/10.1016/j.jbankfin.2010.08.015

38. Kędzior, M. (2011). Międzynarodowa struktura kapitału przedsiębiorstw. Ujęcie rachunkowości i finansów. Warszawa: C.H. Beck.

39. Kim, H., Heshmati, A., \& Aoun, D. (2006). Dynamics of Capital Structure: The Case of Korean Listed Manufacturing Companies. Asian Economic Journal, 20, (3), 275-302. http://dx.doi.org/10.1111/j.1467-8381.2006.00236.x

40. Kraus, A., \& Litzenberger, R. H. (1973). A state-preference model of optimal financial leverage. The Journal of Finance, 28, (4), 911922. http://dx.doi.org/10.1111/j.1540-6261.1973.tb01415.x

41. La Rocca, M., La Rocca, T., \& Cariola, A. (2011). Capital Structure Decisions during a Firm's Life Cycle. Small Business Economics, 37, 107-130. http://dx.doi.org/10.1007/s11187-0099229-Z

42. Lee, H., Oh, S., \& Park, K. (2014). How do capital structure policies of emerging markets differ from those of developed economies? Survey evidence from Korea. Emerging Markets Finance \& Trade, 50, (2), 34-72. http://dx.doi.org/10.2753/REE1540-496X500203

43. Margaritis, D., \& Psillaki, M. (2007). Capital Structure and Firm Efficiency. Journal of Business Finance \& Accounting, 34, (9-10), 1447-1469. http://dx.doi.org/10.1111/j.1468-5957.2007.02056.x

44. Mátyás, L., \& Sevestre, P. (Eds.). (2008). The Econometrics of Panel Data, Fundamentals and Recent Developments in panel data. Journal of Business Finance \& Accounting, 28, (1-2), 175-198.

45. Mazur, K. (2007). The Determinants of Capital Structure Choice: Evidence from Polish Companies. International Advances in Economic Research, 13, (4), 495-514. http://dx.doi.org/10.1007/s11294-007-9114-y

46. Michaelas, N., Chittenden, F., \& Poutziouris, P. (1999). Financial policy and capital structure choice in UK SMEs: Empirical evidence from company panel data. Small business economics, 12, (2), 113-130. http://dx.doi.org/10.1023/A:1008010724051

47. Munyo, I. (2006). The financial structure of firms in an economy without capital markets. Revista de Ciencias Empresariales y Economía, 5, 131-149.

48. Myers, S. C. (1977). Determinants of corporate borrowing. Journal of financial economics, 5, (2), 147-175. http://dx.doi.org/10.1016/0304-405X(77)90015-0

49. Myers, S. C. (1984). The capital structure puzzle. The Journal of Finance, 39, (3), 574-592. http://dx.doi.org/10.1111/j.15406261.1984.tb03646.x

50. Myers, S. C. (2001). Capital structure. Journal of Economic perspectives, 81-102. http://dx.doi.org/10.1257/jep.15.2.81

51. Myers, S. C., \& Majluf, N. S. (1984). Corporate Financing and Investment Decisions When Firms Have Information Investors Do Not Have. Journal of Financial Economics, 13, 187-222. http://dx.doi.org/10.1016/0304-405X(84)90023-0

52. Nehrebecka, N., \& Dzik, A. (2012). Konstrukcja miernika szans na bankructwo firmy. Materiaty $i$ Studia NBP, 280.

53. Nguyen, D. T. T., Diaz-Rainey, I., \& Gregoriou, A. (2014). Determinants of the Capital Structure of Listed Vietnamese Companies. Journal of Southeast Asian Economies, 31, (3), 41231. http://dx.doi.org/10.1355/ae31-3e 
Social Sciences /

Socialiniai mokslai. 2015. Nr. 1 (87)

54. Ozkan, A. (2001). Determinants of capital structure and adjustment to long run target: evidence from UK company. http://dx.doi.org/10.1111/j.1540-6261.1995.tb05184.x

55. Rajan, R. G., \& Zingales, L. (1995). What do we know about capital structure? Some evidence from international data. Journal of Finance, 50, 1421-1460.

56. Ross, S. A. (1977). The determination of financial structure: the incentive-signalling approach. The Bell Journal of Economics, 2340. http://dx.doi.org/10.2307/3003485

57. Serrasqueiro, Z., Armada, M., \& Nunes, P. (2011). Pecking Order Theory versus Trade-Off Theory: are service SMEs' capital structure decisions different? Service Business, 5, (4), 381-409. http://dx.doi.org/10.1007/s11628-011-0119-5

58. Theory and Practice. Series: Advanced Studies in Theoretical and Applied Econometrics, 46, 89-110, 249 -279, 603 - 623. Springer.

59. Vanacker, T. R., \& Manigart, S. (2010). Pecking order and debt capacity considerations for high-growth companies seeking financing. Small Business Economics, 35, (1), 53-69. http://dx.doi.org/10.1007/s11187-008-9150-x

60. Vidal, J. S., \& Martin-Ugedo, J. F. (2005). Financing Preferences of Spanish Firms: Evidence on the Pecking Order Theory. Review of Quantitive Finance and Accounting, 25.

61. Wu, L., \& Yue, H. (2009). Corporate tax, capital structure, and the accessibility of bank loans: Evidence from China. Journal of Banking \& Finance, 33, (1), 30-38. http://dx.doi.org/10.1016/j.jbankfin.2006.10.030

\section{A. Białek-Jaworska, N. Nehrebecka}

Lenkijos kompanijų skolų finansavimo prioritetus lemiantys veiksniai

Santrauka

Straipsnyje siekiama identifikuoti veiksnius, lemiančius Lenkijos ne finansu srities kompaniju pasirinkimus, susijusius su skolų finansavimu, atsižvelgiant $i$ monetarinès politikos poveikị ir metus. Studija atlikta taikant apibendrintą momentų metodą (GMM) kompanijų duomenu imčiai 1995-2012 metais (800 stebẻjimų).

Finansinis svertas yra teorinių diskusijų ir empirinių studijų, besiremiančiu kompanijos ataskaitose fiksuojamais vieneto duomenimis, objektas. Tačiau straipsniuose nepateikiamos vienareikšmès išvados. Analizuojant ịmonių kapitalo struktūrą, akcentuojamas kompanijos dydis. Ir kompromiso teorija, ir pasirinkimo teorija pabrěžia teigiamą koreliaciją tarp kompanijos dydžio ir finansinio sverto, kadangi didesnè pelno diversifikacija ir mažesnis kintamumas paaštrina informacijos asimetrijos problemą. Rajan ir Zingales (1995) teigia, kad didesnès kompanijos yra labiau diversifikuotos ir rečiau patiria finansines problemas, todèl kompanijos dydis gali būti atvirkščiai proporcingas bankroto galimybei ir turèti teigiamą poveiki skolų lygiui. Kompanijos dydis gali būti vertinamas kaip informacijos asimetrijos tarp kompanijos ir rinkos atsvara. Didesnès firmos dažnai viešina žymiai daugiau informacijos, nei mažieji verslai, tokiu būdu pagerindamos savo ịsiskolinimo sąlygas. Dauguma studiju atskleidžia teigiamą kompanijos dydžio poveiki jos finansiniam svertui (pvz., Chen, 2004; Kim et al., 2006; Joeveer, 2013).

Straipsnyje pateikiama analizè remiasi egzistuojančiomis žiniomis apie veiksnius, lemiančius Lenkijos firmų kapitalo struktūros lygị. Ši
A. Białek-Jaworska, N. Nehrebecka. Determinants of Polish Companies' Debt Financing Preferences

studija yra originalus darbas, atliktas analizuojant viešojo ir privataus sektoriaus kompanijas, neịtrauktas i biržos sąrašus. Be to, demesys turi būti skiriamas bankroto rizikos kintamojo, apskaičiuojamo inovatyviu būdu, apibrèžimui, taip pat kintamajam, atspindinčiam gebejjimą generuoti pinigų perteklių (apyvartoje esantị pinigų srautą skaičiuojant netiesioginiu metodu). Santykis, leidžiantis nustatyti kompanijos bankroto tikimybę, buvo sukonstruotas taikant tradicinių logistinès transgresijos ir vertinimo metodų kombinaciją.

Straipsni sudaro šios dalys: įvadineje dalyje pateikiamas teorinis pagrindimas ir tyrimo hipotezès, empirinis tyrimas ir rezultatų diskusija, remiantis literatūros šaltiniais. Empirinè analizė remiasi kompanijų balanso ataskaitomis, pelno ir nuostolio duomenimis, Lenkijos kompaniju užregistruotais 1995 - 2012 metinèse statistinėse F-02 ataskaitose ir ketvirčio ataskaitose F-01/I-0. Straipsnyje pateikiami modeliai apima individualaus, sektoriui būdingo ir nuo laiko priklausančio poveikio vertinimą. Parametrai buvo apskaičiuoti taikant sistemos apibendrintą momentu metodą (GMM) (Arellano ir Bover, 1995; Blundell ir Bond, 1998). Atlikta analizè, rodanti, kaip mažų ir vidutinių ịmonių mokesčių problemos bei smulkiojo verslo augimo galimybès veikia skolų finansavimą, turètų padèti bankams pritaikyti savo paslaugas mažų ir vidutinių įmonių sektoriaus poreikiams. Teigiamas bankroto rizikos poveikis skolu finansavimui, paskaičiuotas taikant tradiciniu logistinès transgresijos ir vertinimo metodų kombinaciją, turètų paveikti bankų paskolu komitetų sprendimus kuriant kreditabilumo vertinimo ir paskolų teikimo procedūras. Šiuo aspektu pridètinę vertę turi empiriniai ịrodymai, kad Lenkijos ịstojimas ị Europos Sajungą ir prieiga prie ES finansavimo sumažino mažuju imoniu išorinio finansavimo poreiki 2004-2008, o ES šalis apėmusi finansinè krizė (2009-2010) lèmé išorinio finansavimo sumažèjimą. Tyrimo rezultatai parodè, kad koreliacija tarp pelningumo (finansavimosi) ir skolų finansavimo buvo neigiama didžiụjų ịmonių grupeje, o neigiamas ryšys tarp greito likvidumo rodiklio ir sverto, pastebėtas nepriklausomai nuo kompanijos dydžio, neprieštarauja pasirinkimo eilès teorijai. Be to, analizė rodo labai nedidelę monetarinès politikos įtaką Lenkijos kompanijų skolų finansavimo sprendimams.

Reikšminiai žodžiai: svertas, kapitalo struktūra, pasirinkimo eilès teorija, kompromiso teorija, apibendrintas momentų metodas (GMM).

First received: November, 2014

Accepted for publication: December, 2014 


\section{Determinants of financial leverage}

\begin{tabular}{|c|c|c|c|c|c|c|c|c|}
\hline \multirow{2}{*}{$\begin{array}{l}\text { Explanatory } \\
\text { variable }\end{array}$} & \multicolumn{3}{|c|}{ Models with effect of the year } & \multicolumn{5}{|c|}{ Models with control variables for the monetary policy impact } \\
\hline & $\begin{array}{c}\text { MODEL } \\
\text { I } \\
\text { Large firms } \\
\text { b (se) }\end{array}$ & $\begin{array}{l}\text { MODEL } \\
\text { II } \\
\text { Medium } \\
\text { size firms } \\
\text { b (se) }\end{array}$ & $\begin{array}{c}\text { MODEL } \\
\text { III } \\
\text { Small firms } \\
\text { b (se) }\end{array}$ & $\begin{array}{c}\text { MODEL } \\
\text { IV } \\
\text { Large firms } \\
\text { nominal } \\
\text { WIBOR, } \\
\text { EER } \\
\text { b (se) }\end{array}$ & $\begin{array}{l}\text { MODEL VII } \\
\text { Large firms } \\
\text { real WIBOR } \\
\text { b (se) }\end{array}$ & $\begin{array}{c}\text { MODEL } \\
\text { VIII } \\
\text { Large firms } \\
\text { REER } \\
\text { b (se) }\end{array}$ & $\begin{array}{c}\text { MODEL } \\
\text { V } \\
\text { Medium size } \\
\text { firms } \\
\text { b (se) }\end{array}$ & $\begin{array}{c}\text { MODEL } \\
\text { VI } \\
\text { Small firms } \\
\\
\text { b (se) }\end{array}$ \\
\hline $\begin{array}{l}\text { Financial } \\
\text { leverage one } \\
\text { period lagged }\end{array}$ & $\begin{array}{l}0,6827 * * * \\
(0,0441)\end{array}$ & $\begin{array}{l}0,6935 * * * \\
(0,0386)\end{array}$ & $\begin{array}{l}0,6191 * * * \\
(0,0328)\end{array}$ & $\begin{array}{l}0,6844 * * * \\
(0,0416)\end{array}$ & $\begin{array}{l}0,6578 * * * \\
(0,0393)\end{array}$ & $\begin{array}{l}0,6992 * * * \\
(0,0442)\end{array}$ & $\begin{array}{l}0,6974 * * * \\
(0,0357)\end{array}$ & $\begin{array}{l}0,7554 * * * \\
(0,0700)\end{array}$ \\
\hline $\begin{array}{l}\text { Financial } \\
\text { leverage two } \\
\text { periods lagged }\end{array}$ & & & $\begin{array}{l}0,0574 * * * \\
(0,0090)\end{array}$ & & & & & $\begin{array}{l}-0,0270 \\
(0,0546)\end{array}$ \\
\hline 1997 & $\begin{array}{l}-0,0036 \\
(0,0145)\end{array}$ & $\begin{array}{l}-0,0031 \\
(0,0163)\end{array}$ & $\begin{array}{l}0,0131 \\
(0,0131)\end{array}$ & & & & & \\
\hline 1998 & $\begin{array}{l}0,0101 \\
(0,0106)\end{array}$ & $\begin{array}{l}-0,0029 \\
(0,0109)\end{array}$ & $\begin{array}{l}0,0167 \# \\
(0,0106)\end{array}$ & & & & & \\
\hline 1999 & $\begin{array}{l}0,0151 \# \\
(0,0094)\end{array}$ & $\begin{array}{l}0,0011 \\
(0,0097)\end{array}$ & $\begin{array}{l}0,0248 * * * \\
(0,0071)\end{array}$ & $\begin{array}{l}0,0214^{* * *} \\
(0,0052)\end{array}$ & $\begin{array}{l}0,0239 * * * \\
(0,0047)\end{array}$ & $\begin{array}{l}0,0099 * * \\
(0,0047)\end{array}$ & $\begin{array}{l}0,0090 \# \\
(0,0056)\end{array}$ & $\begin{array}{l}0,0157^{*} \\
(0,0080)\end{array}$ \\
\hline 2000 & $\begin{array}{l}0,0228 * * * \\
(0,0078)\end{array}$ & $\begin{array}{l}0,0121 \# \# \\
(0,0086)\end{array}$ & $\begin{array}{l}0,0280 * * * \\
(0,0066)\end{array}$ & $\begin{array}{l}0,0260 * * * \\
(0,0066)\end{array}$ & $\begin{array}{l}0,0222 * * * \\
(0,0045)\end{array}$ & $\begin{array}{l}0,0205^{* * *} \\
(0,0043)\end{array}$ & $\begin{array}{l}0,0155^{* *} \\
(0,0065)\end{array}$ & $\begin{array}{l}0,0130 \# \\
(0,0081)\end{array}$ \\
\hline 2001 & $\begin{array}{l}0,0138 * * \\
(0,0062)\end{array}$ & $\begin{array}{l}-0,0005 \\
(0,0067)\end{array}$ & $\begin{array}{l}0,0180^{* * *} \\
(0,0056)\end{array}$ & $\begin{array}{l}0,0008 \\
(0,0059)\end{array}$ & $\begin{array}{l}0,0053 \\
(0,0047)\end{array}$ & $\begin{array}{l}0,0102 * \\
(0,0054)\end{array}$ & $\begin{array}{l}0,0008 \\
(0,0060)\end{array}$ & $\begin{array}{l}0,0157 * * \\
(0,0063)\end{array}$ \\
\hline 2002 & & & $\begin{array}{l}-0,0011 \\
(0,0053)\end{array}$ & $\begin{array}{l}-0,0144 * * * \\
(0,0050)\end{array}$ & $\begin{array}{l}0,0023 \\
(0,0046)\end{array}$ & $\begin{array}{l}-0,0067 \\
(0,0064)\end{array}$ & & \\
\hline 2003 & $\begin{array}{l}0,0063 \# \# \\
(0,0048)\end{array}$ & $\begin{array}{l}-0,0032 \\
(0,0044)\end{array}$ & & & & $\begin{array}{l}0,0018 \\
(0,0054)\end{array}$ & & \\
\hline 2004 & $\begin{array}{l}-0,0148 * * * \\
(0,0051)\end{array}$ & $\begin{array}{l}-0,0193 * * * \\
(0,0048)\end{array}$ & $\begin{array}{l}-0,0213^{* * *} \\
(0,0024)\end{array}$ & & & & & \\
\hline 2005 & $\begin{array}{l}-0,0035 \\
(0,0053)\end{array}$ & $\begin{array}{l}-0,0070 \# \# \\
(0,0053)\end{array}$ & $\begin{array}{l}-0,0078^{* *} \\
(0,0036)\end{array}$ & $\begin{array}{l}-0,0049 \# \# \\
(0,0037)\end{array}$ & & & $\begin{array}{l}-0,0163^{* * *} \\
(0,0051)\end{array}$ & \\
\hline 2006 & $\begin{array}{l}0,0078 * \\
(0,0047)\end{array}$ & $\begin{array}{l}-0,0046 \\
(0,0044)\end{array}$ & $\begin{array}{l}-0,0108 * * * \\
(0,0027)\end{array}$ & $\begin{array}{l}0,0064 * * \\
(0,0030)\end{array}$ & $\begin{array}{l}0,0153 * * * \\
(0,0031)\end{array}$ & $\begin{array}{l}0,0134 * * * \\
(0,0043)\end{array}$ & $\begin{array}{l}-0,0059 * * \\
(0,0025)\end{array}$ & $\begin{array}{l}0,0014 \\
(0,0019)\end{array}$ \\
\hline 2007 & $\begin{array}{l}-0,0018 \\
(0,0048)\end{array}$ & $\begin{array}{l}-0,0061 \# \# \\
(0,0044)\end{array}$ & $\begin{array}{l}-0,0162^{* * *} \\
(0,0034)\end{array}$ & & & $\begin{array}{l}0,0074 \# \\
(0,0049)\end{array}$ & & \\
\hline 2008 & $\begin{array}{l}0,0038 \\
(0,0044)\end{array}$ & $\begin{array}{l}-0,0068 * \\
(0,0036)\end{array}$ & $\begin{array}{l}-0,0100 * * * \\
(0,0036)\end{array}$ & $\begin{array}{l}-0,0052 \\
(0,0047)\end{array}$ & $\begin{array}{l}0,0103 * * * \\
(0,0037)\end{array}$ & $\begin{array}{l}0,0015 \\
(0,0047)\end{array}$ & $\begin{array}{l}-0,0188 * * * \\
(0,0050)\end{array}$ & $\begin{array}{l}-0,0170 * * * \\
(0,0035)\end{array}$ \\
\hline 2009 & $\begin{array}{l}-0,0232^{* * *} \\
(0,0058)\end{array}$ & $\begin{array}{l}-0,0244^{* * *} \\
(0,0054)\end{array}$ & $\begin{array}{l}-0,0121^{* * *} \\
(0,0042)\end{array}$ & $\begin{array}{l}-0,0206 * * * \\
(0,0048)\end{array}$ & $\begin{array}{l}-0,0130 * * * \\
(0,0048)\end{array}$ & $\begin{array}{l}-, 0180 * * * \\
(0,0053)\end{array}$ & & $\begin{array}{l}-0,0063 \\
(0,0056)\end{array}$ \\
\hline 2010 & $\begin{array}{l}-0,0004 \\
(0,0044)\end{array}$ & $\begin{array}{l}-0,0037 \\
(0,0039)\end{array}$ & $\begin{array}{l}-0,0041 \# \# \\
(0,0030)\end{array}$ & $\begin{array}{l}0,0015 \\
(0,0032)\end{array}$ & $\begin{array}{l}0,0037 \\
(0,0035)\end{array}$ & $\begin{array}{l}0,0072 * \\
(0,0039)\end{array}$ & $\begin{array}{l}0,0070 * * \\
(0,0031)\end{array}$ & $\begin{array}{l}0,0062 * \\
(0,0033)\end{array}$ \\
\hline $\begin{array}{l}\text { Exporter } \\
\text { unspecialised }\end{array}$ & $\begin{array}{l}0,0043 \\
(0,0323)\end{array}$ & $\begin{array}{l}-0,0415 \\
(0,0340)\end{array}$ & $\begin{array}{l}-0,0050 \\
(0,0388)\end{array}$ & $\begin{array}{l}-0,0227 \\
(0,0284)\end{array}$ & $\begin{array}{l}-0,0115 \\
(0,0300)\end{array}$ & $\begin{array}{l}-0,0209 \\
(0,0303)\end{array}$ & $\begin{array}{l}-0,0930 * * * \\
(0,0301)\end{array}$ & $\begin{array}{l}-0,0700^{* *} \\
(0,0353)\end{array}$ \\
\hline $\begin{array}{l}\text { Exporter } \\
\text { specialized }\end{array}$ & $\begin{array}{l}0,0348 \\
(0,0371)\end{array}$ & $\begin{array}{l}-0,0242 \\
(0,0378)\end{array}$ & $\begin{array}{l}0,0307 \\
(0,0563)\end{array}$ & $\begin{array}{l}0,0312 \\
(0,0332)\end{array}$ & $\begin{array}{l}0,0489 \# \\
(0,0336)\end{array}$ & $\begin{array}{l}0,0125 \\
(0,0351)\end{array}$ & $\begin{array}{l}-0,0485 \# \# \\
(0,0361)\end{array}$ & $\begin{array}{l}0,0396 \\
(0,0518)\end{array}$ \\
\hline $\begin{array}{l}\text { The share of } \\
\text { foreign } \\
\text { ownership }\end{array}$ & $\begin{array}{l}-0,0119 \\
(0,0327)\end{array}$ & $\begin{array}{l}0,0518 \# \# \\
(0,0361)\end{array}$ & $\begin{array}{l}-0,0755 \# \\
(0,0466)\end{array}$ & $\begin{array}{l}-0,0188 \\
(0,0302)\end{array}$ & $\begin{array}{l}-0,0143 \\
(0,0294)\end{array}$ & $\begin{array}{l}-0,0027 \\
(0,0305)\end{array}$ & $\begin{array}{l}0,0607 \# \\
(0,0373)\end{array}$ & $\begin{array}{l}-0,0414 \\
(0,0477)\end{array}$ \\
\hline Construction & $\begin{array}{l}0,0537 \# \# \\
(0,0378)\end{array}$ & $\begin{array}{l}0,0100 \\
(0,0291)\end{array}$ & $\begin{array}{l}-0,0148 \\
(0,0324)\end{array}$ & $\begin{array}{l}0,0237 \\
(0,0351)\end{array}$ & $\begin{array}{l}0,0296 \\
(0,0348)\end{array}$ & $\begin{array}{l}0,0242 \\
(0,0360)\end{array}$ & $\begin{array}{l}-0,0229 \\
(0,0278)\end{array}$ & $\begin{array}{l}-0,0541 * \\
(0,0296)\end{array}$ \\
\hline Trade & $\begin{array}{l}0,0232 \\
(0,0440)\end{array}$ & $\begin{array}{l}0,0226 \\
(0,0321)\end{array}$ & $\begin{array}{l}0,0424 \# \\
(0,0269)\end{array}$ & $\begin{array}{l}0,0197 \\
(0,0409)\end{array}$ & $\begin{array}{l}0,0518 \\
(0,0410)\end{array}$ & $\begin{array}{l}0,0089 \\
(0,0441)\end{array}$ & $\begin{array}{l}-0,0102 \\
(0,0295)\end{array}$ & $\begin{array}{l}0,0191 \\
(0,0254)\end{array}$ \\
\hline Transport & $\begin{array}{l}-0,0405 \\
(0,0504)\end{array}$ & $\begin{array}{l}0,0671 \# \# \\
(0,0513)\end{array}$ & $\begin{array}{l}-0,0393 \\
(0,0639)\end{array}$ & $\begin{array}{l}-0,0522 \\
(0,0440)\end{array}$ & $\begin{array}{l}-0,0270 \\
(0,0438)\end{array}$ & $\begin{array}{l}-0,0561 \\
(0,0474)\end{array}$ & $\begin{array}{l}0,0299 \\
(0,0522)\end{array}$ & $\begin{array}{l}-0,0788 \# \# \\
(0,0582)\end{array}$ \\
\hline Other services & $\begin{array}{l}-0,0364 \\
(0,0349)\end{array}$ & $\begin{array}{l}-0,0552 \# \\
(0,0351)\end{array}$ & $\begin{array}{l}-0,0388 \\
(0,0304)\end{array}$ & $\begin{array}{l}-0,0290 \\
(0,0335)\end{array}$ & $\begin{array}{l}-0,0098 \\
(0,0335)\end{array}$ & $\begin{array}{l}-0,0288 \\
(0,0358)\end{array}$ & $\begin{array}{l}-0,1262 * * * \\
(0,0326)\end{array}$ & $\begin{array}{l}-0,0639 * * \\
(0,0276)\end{array}$ \\
\hline $\begin{array}{l}\text { Limited } \\
\text { partnerships }\end{array}$ & $\begin{array}{l}0,3169 * \\
(0,1793)\end{array}$ & $\begin{array}{l}0,4021 * * * \\
(0,1425)\end{array}$ & $\begin{array}{l}-0,1104 \\
(0,2731)\end{array}$ & $\begin{array}{l}0,2888 * \\
(0,1579)\end{array}$ & $\begin{array}{l}0,4367 * * * \\
(0,1634)\end{array}$ & $\begin{array}{l}0,2641 \# \\
(0,1797)\end{array}$ & $\begin{array}{l}0,3547 * * * \\
(0,1318)\end{array}$ & $\begin{array}{l}-0,3786 \# \\
(0,2541)\end{array}$ \\
\hline $\begin{array}{l}\text { Limited liability } \\
\text { companies }\end{array}$ & $\begin{array}{l}0,0195 \\
(0,0413)\end{array}$ & $\begin{array}{l}-0,0459 * \\
(0,0273)\end{array}$ & $\begin{array}{l}-0,0322 \\
(0,0380)\end{array}$ & $\begin{array}{l}0,0170 \\
(0,0335)\end{array}$ & $\begin{array}{l}0,0132 \\
(0,0320)\end{array}$ & $\begin{array}{l}0,0109 \\
(0,0338)\end{array}$ & $\begin{array}{l}-0,0710^{* *} \\
(0,0276)\end{array}$ & $\begin{array}{l}0,0150 \\
(0,0333)\end{array}$ \\
\hline $\begin{array}{l}\text { Joint-stock } \\
\text { companies }\end{array}$ & $\begin{array}{l}-0,0084 \\
(0,0353)\end{array}$ & $\begin{array}{l}-0,0069 \\
(0,0382)\end{array}$ & $\begin{array}{l}-0,0034 \\
(0,0834)\end{array}$ & $\begin{array}{l}-0,0100 \\
(0,0299)\end{array}$ & $\begin{array}{l}-0,0152 \\
(0,0299)\end{array}$ & $\begin{array}{l}-0,0120 \\
(0,0303)\end{array}$ & $\begin{array}{l}-0,0137 \\
(0,0385)\end{array}$ & $\begin{array}{l}0,0426 \\
(0,0751)\end{array}$ \\
\hline
\end{tabular}




\begin{tabular}{|c|c|c|c|c|c|c|c|c|}
\hline $\begin{array}{l}\text { Foreign } \\
\text { companies }\end{array}$ & $\begin{array}{l}0,0938 \\
(0,8266)\end{array}$ & & & $\begin{array}{l}-0,3918 \\
(0,7791)\end{array}$ & $\begin{array}{l}-0,3808 \\
(0,7405)\end{array}$ & $\begin{array}{l}-0,5240 \\
(0,8519)\end{array}$ & & \\
\hline $\begin{array}{l}\text { State-owned } \\
\text { enterprises }\end{array}$ & $\begin{array}{l}-0,0063 \\
(0,0591)\end{array}$ & $\begin{array}{l}0,0129 \\
(0,0655)\end{array}$ & $\begin{array}{l}-0,3317 * * \\
(0,1681)\end{array}$ & $\begin{array}{l}0,0334 \\
(0,0472)\end{array}$ & $\begin{array}{l}0,0187 \\
(0,0458)\end{array}$ & $\begin{array}{l}0,0240 \\
(0,0487)\end{array}$ & $\begin{array}{l}0,0387 \\
(0,0528)\end{array}$ & $\begin{array}{l}-0,1773 \\
(0,1440)\end{array}$ \\
\hline Cooperatives & & & $\begin{array}{l}-0,0518 \\
(0,0459)\end{array}$ & & & & & $\begin{array}{l}0,0037 \\
(0,0407)\end{array}$ \\
\hline Others & $\begin{array}{l}0,0243 \\
(0,0910)\end{array}$ & $\begin{array}{l}-0,0432 \\
(0,0442)\end{array}$ & $\begin{array}{l}-0,0821 * \\
(0,0473)\end{array}$ & $\begin{array}{l}-0,0197 \\
(0,0840)\end{array}$ & $\begin{array}{l}-0,0016 \\
(0,0795)\end{array}$ & $\begin{array}{l}-0,0190 \\
(0,0878)\end{array}$ & $\begin{array}{l}-0,0562 \\
(0,0460)\end{array}$ & $\begin{array}{l}-0,0166 \\
(0,0415)\end{array}$ \\
\hline Collateral & $\begin{array}{l}-0,2299 * \\
(0,1260)\end{array}$ & $\begin{array}{l}-0,4503 * * * \\
(0,1230)\end{array}$ & $\begin{array}{l}-0,2411 \# \# \\
(0,1763)\end{array}$ & $\begin{array}{l}-0,2639 * * \\
(0,1234)\end{array}$ & $\begin{array}{l}-0,2994^{* * *} \\
(0,1079)\end{array}$ & $\begin{array}{l}-0,2362 * \\
(0,1278)\end{array}$ & $\begin{array}{l}-0,4852 * * * \\
(0,1251)\end{array}$ & $\begin{array}{l}-0,3118 * * \\
(0,1403)\end{array}$ \\
\hline $\begin{array}{l}\text { Collateral } \\
\text { one period } \\
\text { lagged }\end{array}$ & $\begin{array}{l}0,1261 \\
(0,1147)\end{array}$ & $\begin{array}{l}0,3645 * * * \\
(0,1155)\end{array}$ & $\begin{array}{l}0,2982^{*} \\
(0,1648)\end{array}$ & $\begin{array}{l}0,1007 \\
(0,1115)\end{array}$ & $\begin{array}{l}0,1273 \\
(0,0970)\end{array}$ & $\begin{array}{l}0,0708 \\
(0,1149)\end{array}$ & $\begin{array}{l}0,3863 * * * \\
(0,1172)\end{array}$ & $\begin{array}{l}0,2429 * \\
(0,1350)\end{array}$ \\
\hline $\begin{array}{l}\text { Cumulated } \\
\text { return on equity }\end{array}$ & $\begin{array}{l}0,0254 * * \\
(0,0120)\end{array}$ & $\begin{array}{l}0,0035 \\
(0,0130)\end{array}$ & $\begin{array}{l}0,0001 \\
(0,0139)\end{array}$ & $\begin{array}{l}0,0139 \\
(0,0110)\end{array}$ & & & $\begin{array}{l}-0,0042 \\
(0,0140)\end{array}$ & $\begin{array}{l}-0,0153 \\
(0,0123)\end{array}$ \\
\hline $\begin{array}{l}\text { Lagged } \\
\text { cumulated return } \\
\text { on equity }\end{array}$ & & & & $\begin{array}{l}0,0139 \\
(0,0110)\end{array}$ & $\begin{array}{l}0,0175^{*} \\
(0,0104)\end{array}$ & $\begin{array}{l}0,0178 \# \\
(0,0114)\end{array}$ & & \\
\hline Self-financing & $\begin{array}{l}0,0481 \\
(0,0564)\end{array}$ & $\begin{array}{l}0,0619 \\
(0,0486)\end{array}$ & $\begin{array}{l}0,0863 * \\
(0,0520)\end{array}$ & $\begin{array}{l}-0,0020 \\
(0,0498)\end{array}$ & $\begin{array}{l}-0,0118 \\
(0,0450)\end{array}$ & $\begin{array}{l}-0,0179 \\
(0,0514)\end{array}$ & $\begin{array}{l}0,0650 \\
(0,0537)\end{array}$ & $\begin{array}{l}0,0866 * \\
(0,0484)\end{array}$ \\
\hline $\begin{array}{l}\text { Self-financing } \\
\text { one period } \\
\text { lagged }\end{array}$ & $\begin{array}{l}-0,0197 * * \\
(0,0077)\end{array}$ & $\begin{array}{l}0,0562 \# \# \\
(0,0425)\end{array}$ & $\begin{array}{l}0,0228 \\
(0,0328)\end{array}$ & $\begin{array}{l}-0,0179 * * \\
(0,0077)\end{array}$ & $\begin{array}{l}-0,0194 * * * \\
(0,0074)\end{array}$ & $\begin{array}{l}-0,0116 \# \\
(0,0078)\end{array}$ & $\begin{array}{l}0,0740^{*} \\
(0,0434)\end{array}$ & $\begin{array}{l}0,0510 \# \\
(0,0320)\end{array}$ \\
\hline $\begin{array}{l}\text { Quick ratio } \\
\text { measure }\end{array}$ & $\begin{array}{l}-0,0183^{* * *} \\
(0,0054)\end{array}$ & $\begin{array}{l}-0,0216 * * * \\
(0,0048)\end{array}$ & $\begin{array}{l}-0,0118 * * * \\
(0,0045)\end{array}$ & $\begin{array}{l}-0,0191^{* * *} \\
(0,0053)\end{array}$ & $\begin{array}{l}-0,0221^{* * *} \\
(0,0049)\end{array}$ & $\begin{array}{l}-, 0185^{* * *} \\
(0,0055)\end{array}$ & $\begin{array}{l}-0,0212 * * * \\
(0,0050)\end{array}$ & $\begin{array}{l}-0,0151^{* * *} \\
(0,0054)\end{array}$ \\
\hline $\begin{array}{l}\text { Non-debt tax } \\
\text { shield }\end{array}$ & $\begin{array}{l}-42,5706 \\
(285,5151)\end{array}$ & $\begin{array}{l}-1041,7 * * * \\
(356,8246)\end{array}$ & $\begin{array}{l}76,1211 \\
(417,8103)\end{array}$ & $\begin{array}{l}-243,1448 \\
(247,7538)\end{array}$ & $\begin{array}{l}-346,0820 \# \\
(231,8088)\end{array}$ & $\begin{array}{l}-208,6487 \\
(259,529)\end{array}$ & $\begin{array}{l}-1355,8 * * * \\
(311,9892)\end{array}$ & $\begin{array}{l}280,2306 \\
(384,4269)\end{array}$ \\
\hline $\begin{array}{l}\text { Lagged non-debt } \\
\text { tax shield }\end{array}$ & $\begin{array}{l}288,42 * * * \\
(107,3243)\end{array}$ & $\begin{array}{l}616,2416 \# \\
(374,9313)\end{array}$ & $\begin{array}{l}-380,2417 \\
(381,4218)\end{array}$ & $\begin{array}{l}297,0319 * * * \\
(104,1587)\end{array}$ & $\begin{array}{l}318,6926 * * * \\
(101,1731)\end{array}$ & $\begin{array}{l}121,0479 \\
(97,1634)\end{array}$ & $\begin{array}{l}965,7374 * * * \\
(317,2596)\end{array}$ & $\begin{array}{l}-526,0102 * \\
(292,4267)\end{array}$ \\
\hline $\begin{array}{l}\text { Interest tax } \\
\text { shield }\end{array}$ & $\begin{array}{l}0,9357 * * \\
(0,4178)\end{array}$ & $\begin{array}{l}1,4911 * * * \\
(0,3687)\end{array}$ & $\begin{array}{l}1,2411^{* * *} \\
(0,3362)\end{array}$ & $\begin{array}{l}1,1404 * * * \\
(0,3809)\end{array}$ & $\begin{array}{l}1,2505 * * * \\
(0,3647)\end{array}$ & $\begin{array}{l}1,0463 * * * \\
(0,3906)\end{array}$ & $\begin{array}{l}1,3391 * * * \\
(0,3356)\end{array}$ & $\begin{array}{l}1,0518 * * * \\
(0,3202)\end{array}$ \\
\hline $\begin{array}{l}\text { Growth } \\
\text { opportunities }\end{array}$ & $\begin{array}{l}-0,0146 \\
(0,0326)\end{array}$ & $\begin{array}{l}-0,0688^{*} \\
(0,0362)\end{array}$ & $\begin{array}{l}0,0651^{*} \\
(0,0375)\end{array}$ & $\begin{array}{l}-0,0292 \\
(0,0290)\end{array}$ & $\begin{array}{l}-0,0296 \\
(0,0286)\end{array}$ & $\begin{array}{l}-0,0600 * * \\
(0,0286)\end{array}$ & $\begin{array}{l}-0,0288 \\
(0,0311)\end{array}$ & $\begin{array}{l}0,0368 \\
(0,0309)\end{array}$ \\
\hline $\begin{array}{l}\text { Lagged growth } \\
\text { opportunities }\end{array}$ & $\begin{array}{l}-0,0116 * \\
(0,0066)\end{array}$ & $\begin{array}{l}-0,0012 \\
(0,0160)\end{array}$ & $\begin{array}{l}-0,0271 \# \# \\
(0,0196)\end{array}$ & $\begin{array}{l}-0,0088 \# \# \\
(0,0063)\end{array}$ & $\begin{array}{l}-0,0070 \\
(0,0059)\end{array}$ & $\begin{array}{l}-0,0050 \\
(0,0064)\end{array}$ & $\begin{array}{l}-0,0050 \\
(0,0146)\end{array}$ & $\begin{array}{l}-0,0272 \\
(0,0231)\end{array}$ \\
\hline $\begin{array}{l}\text { Effective tax rate } \\
\text { one period } \\
\text { lagged }\end{array}$ & $\begin{array}{l}0,0110 \\
(0,0486)\end{array}$ & $\begin{array}{l}0,1208 \# \\
(0,0807)\end{array}$ & $\begin{array}{l}0,0341 \\
(0,0662)\end{array}$ & $\begin{array}{l}0,0000 \\
(0,0452)\end{array}$ & $\begin{array}{l}-0,0237 \\
(0,0462)\end{array}$ & $\begin{array}{l}0,0742 * \\
(0,0448)\end{array}$ & $\begin{array}{l}0,2282 * * * \\
(0,0712)\end{array}$ & $\begin{array}{l}-0,0094 \\
(0,0614)\end{array}$ \\
\hline $\begin{array}{l}\text { Payment } \\
\text { gridlock measure }\end{array}$ & $\begin{array}{l}0,1061 \\
(0,2186)\end{array}$ & $\begin{array}{l}0,3607 * \\
(0,2061)\end{array}$ & $\begin{array}{l}0,6145^{* *} \\
(0,2478)\end{array}$ & $\begin{array}{l}0,0927 \\
(0,2046)\end{array}$ & $\begin{array}{l}0,1145 \\
(0,1900)\end{array}$ & $\begin{array}{l}0,0876 \\
(0,2118)\end{array}$ & $\begin{array}{l}0,4573 * \\
(0,2368)\end{array}$ & $\begin{array}{l}0,7213 * * * \\
(0,2249)\end{array}$ \\
\hline $\begin{array}{l}\text { Payment } \\
\text { gridlock measure } \\
\text { lagged }\end{array}$ & $\begin{array}{l}-0,1258 \\
(0,1038)\end{array}$ & $\begin{array}{l}-0,2706^{*} \\
(0,1520)\end{array}$ & $\begin{array}{l}-0,4533 * * \\
(0,2071)\end{array}$ & $\begin{array}{l}-0,1139 \\
(0,0918)\end{array}$ & $\begin{array}{l}-0,1199 \\
(0,0875)\end{array}$ & $\begin{array}{l}-0,1020 \\
(0,0951)\end{array}$ & $\begin{array}{l}-0,3460 * \\
(0,1815)\end{array}$ & $\begin{array}{l}-0,5806 * * * \\
(0,1835)\end{array}$ \\
\hline $\begin{array}{l}\text { Inverse } \\
\text { bankruptcy } \\
\text { prediction rate }\end{array}$ & $\begin{array}{l}48,1842 * * * \\
(11,5359)\end{array}$ & $\begin{array}{l}24,1687 \\
(21,5977)\end{array}$ & $\begin{array}{l}15,5090 * \\
(9,3395)\end{array}$ & $\begin{array}{l}48,6342 * * * \\
(10,8992)\end{array}$ & $\begin{array}{l}47,2326 * * * \\
(10,8182)\end{array}$ & $\begin{array}{l}54,8237 * * * \\
(11,2001)\end{array}$ & $\begin{array}{l}43,0053 * \\
(24,3917)\end{array}$ & $\begin{array}{l}22,5773 * * * \\
(7,6034)\end{array}$ \\
\hline $\begin{array}{l}\text { Interest rate } \\
\text { WIBOR3M }\end{array}$ & & & & $\begin{array}{l}-0,1000 * \\
(0,0600)\end{array}$ & & & $\begin{array}{l}-0,0100 \\
(0,0600)\end{array}$ & $\begin{array}{l}0,1800 * * \\
(0,0900)\end{array}$ \\
\hline $\begin{array}{l}\text { Interest rate } \\
\text { WIBOR3M } \\
\text { lagged }\end{array}$ & & & & $\begin{array}{l}0,1500^{* * *} \\
(0,0400)\end{array}$ & & & $\begin{array}{l}0,0700 \# \# \\
(0,0500)\end{array}$ & $\begin{array}{l}0,0400 \\
(0,0500)\end{array}$ \\
\hline $\begin{array}{l}\text { Interest rate } \\
\text { WIBOR3M } \\
\text { two periods } \\
\text { lagged }\end{array}$ & & & & & & & $\begin{array}{l}-0,1400 * * \\
(0,0700)\end{array}$ & $\begin{array}{l}-0,1000 * \\
(0,0600)\end{array}$ \\
\hline $\begin{array}{l}\text { Real interest } \\
\text { rateWIBOR3M }\end{array}$ & & & & & $\begin{array}{l}-0,0723^{*} \\
(0,0401)\end{array}$ & & & \\
\hline $\begin{array}{l}\text { Real interest rate } \\
\text { WIBOR3M } \\
\text { lagged }\end{array}$ & & & & & $\begin{array}{l}0,1434 * * * \\
(0,0322)\end{array}$ & & & \\
\hline $\begin{array}{l}\text { Effective } \\
\text { currency rate }\end{array}$ & & & & $\begin{array}{l}-0,0212 \# \# \\
(0,0200)\end{array}$ & & & $\begin{array}{l}-0,0623^{* * *} \\
(0,0210)\end{array}$ & $\begin{array}{l}-0,0800 * * * \\
(0,0200)\end{array}$ \\
\hline $\begin{array}{l}\text { Effective } \\
\text { currency rate } \\
\text { lagged }\end{array}$ & & & & $\begin{array}{l}0,0845^{* * *} \\
(0,0210)\end{array}$ & & & $\begin{array}{l}0,1728 * * * \\
(0,0311)\end{array}$ & $\begin{array}{l}0,1105^{* * * *} \\
(0,0200)\end{array}$ \\
\hline $\begin{array}{l}\text { Effective } \\
\text { currency rate } \\
\text { two periods } \\
\text { lagged }\end{array}$ & & & & & & & $\begin{array}{l}-0,1321 * * * \\
(0,0207)\end{array}$ & $\begin{array}{l}-0,0101 * * * \\
(0,0204)\end{array}$ \\
\hline $\begin{array}{l}\text { Real effective } \\
\text { currency rate }\end{array}$ & & & & & & $\begin{array}{l}-0,0502 * \\
(0,0326)\end{array}$ & & \\
\hline $\begin{array}{l}\text { Real effective } \\
\text { currency rate }\end{array}$ & & & & & & $\begin{array}{l}0,0501 * * \\
(0,0203)\end{array}$ & & \\
\hline
\end{tabular}




\begin{tabular}{|c|c|c|c|c|c|c|c|c|}
\hline Constant & $\begin{array}{l}0,0429 \\
(0,0649)\end{array}$ & $\begin{array}{l}0,1565^{* *} \\
(0,0772)\end{array}$ & $\begin{array}{l}0,1073^{* *} \\
(0,0520)\end{array}$ & $\begin{array}{l}0,0464 \\
(0,0665)\end{array}$ & $\begin{array}{l}0,1100^{*} \\
(0,0588)\end{array}$ & $\begin{array}{l}0,0955 \# \\
(0,0612)\end{array}$ & $\begin{array}{l}0,1850 * * \\
(0,0764)\end{array}$ & $\begin{array}{l}0,0852 \# \\
(0,0526)\end{array}$ \\
\hline Test & \multicolumn{8}{|c|}{ Test statistic [p-value] } \\
\hline $\begin{array}{l}\text { Arellano-Bond } \\
\text { Test for the first- } \\
\text { order } \\
\text { autocorrelation }\end{array}$ & $\begin{array}{l}-17,487 \\
{[0,0000]}\end{array}$ & $\begin{array}{l}-19,564 \\
{[0,0000]}\end{array}$ & $\begin{array}{l}-16,919 \\
{[0,0000]}\end{array}$ & $\begin{array}{l}-16,684 \\
{[0,0000]}\end{array}$ & $\begin{array}{l}-16,857 \\
{[0,0000]}\end{array}$ & $\begin{array}{l}-18,404 \\
{[0,0000]}\end{array}$ & $\begin{array}{l}-21,476 \\
{[0,0000]}\end{array}$ & $\begin{array}{l}-8,663 \\
{[0,0000]}\end{array}$ \\
\hline $\begin{array}{l}\text { Arellano-Bond } \\
\text { Test for the } \\
\text { second-order } \\
\text { autocorrelation }\end{array}$ & $\begin{array}{l}0,962 \\
{[0,3363]}\end{array}$ & $\begin{array}{l}0,986 \\
{[0,3237]}\end{array}$ & $\begin{array}{l}1,5104 \\
{[0,1309]}\end{array}$ & $\begin{array}{l}0,965 \\
{[0,3343]}\end{array}$ & $\begin{array}{l}0,817 \\
{[0,4130]}\end{array}$ & $\begin{array}{l}0,861 \\
{[0,3890]}\end{array}$ & $\begin{array}{l}1,333 \\
{[0,1824]}\end{array}$ & $\begin{array}{l}2,006 \\
{[0,0549]}\end{array}$ \\
\hline Sargan Test & $\begin{array}{l}94,3061 \\
{[0,3574]}\end{array}$ & $\begin{array}{l}105,406 \\
{[0,0671]}\end{array}$ & $\begin{array}{l}109,946 \\
{[0,0514]}\end{array}$ & $\begin{array}{l}120,115 \\
{[0,1335]}\end{array}$ & $\begin{array}{l}119,520 \\
{[0,1140]}\end{array}$ & $\begin{array}{l}123,003 \\
{[0,0980]}\end{array}$ & $\begin{array}{l}132,576 \\
{[0,0315]}\end{array}$ & $\begin{array}{l}118,812 \\
{[0,0568]}\end{array}$ \\
\hline
\end{tabular}

\#\# Significant at 20\%, \# Significant at 15\%, * Significant at 10\%, ** Significant at 5\%, *** Significant at 1\%.

Source: Author's analysis based on data published by the Central Statistical Office of Poland. 